\title{
Increased Serum Immunoglobulin A Antiphospholipid Antibody Levels in Childhood Henoch-Schönlein Purpura
}

\author{
Çocukluk Çağı Henoch-Shönlein Purpurasında Artmış Serum Immünoglobulin A \\ Antifosfolipid Antikor Düzeyleri
}

\author{
Özgün BAŞARAN KAYA, ${ }^{1}$ Mahmut ÇIVIILİBAL,,${ }^{2}$ Murat ELEVLİ, ${ }^{1}$ Macit KOLDAŞ, ${ }^{3}$ Nilgün SELÇUK DURU ${ }^{1}$ \\ ${ }^{1}$ Department of Pediatrics, Haseki Educational and Research Hospital, İstanbul, Turkey; \\ ${ }^{2}$ Department of Pediatric Nephrology, Haseki Educational and Research Hospital, İstanbul, Turkey; \\ ${ }^{3}$ Department of Biochemistry, Haseki Educational and Research Hospital, İstanbul, Turkey
}

Objectives: This study aims to investigate the possible role of serum immunoglobulin $A(\lg A)$ anti-phospholipid antibodies (aPL) in childhood Henoch-Schönlein purpura (HSP).

Patients and methods: Thirty children with HSP (12 boys, 18 girls; mean age $9.0 \pm 3.1$ years; range 4 to 16 years) and 30 healthy children who were age and gender-matched were enrolled in this study. In addition to the levels of serum immunoglobulins, acute phase reactants, and other biochemical parameters, serum IgA class anti-cardiolipin antibodies ( $\lg A$ aCL) and $\lg A$ class anti- $\beta_{2^{-}}$ glycoprotein I antibodies (IgA a $\beta_{2}$-GPI) were measured. Blood samples from these patients were collected at both the acute and convalescent stages, and the $\lg \mathrm{A} a C L$ and $\lg \mathrm{A} a \beta_{2}-\mathrm{GPI}$ antibodies were measured by enzyme-linked immunosorbent assay (ELISA).

Results: Serum $\lg A$ aCL and $\lg A$ a $\beta_{2}$-GPI levels were significantly higher in children with HSP than in the controls $(2.12 \pm 0.56 \mathrm{U} / \mathrm{mL}$ versus $1.57 \pm 0.31 \mathrm{U} / \mathrm{mL}, p<0.001$ and $2.32 \pm 1.84 \mathrm{U} / \mathrm{mL}$ versus $0.69 \pm 0.64 \mathrm{U} / \mathrm{mL}, p<0.001$, respectively). The levels of these antibodies decreased significantly in the remission stage of the disease. In the regression analysis, the serum $\lg A$ level was the only independent predictor of the increased $\operatorname{IgA} \mathrm{aCL}$ and $\lg \mathrm{A}$ $a \beta_{2}$-GPI antibodies ( $\beta$ : 0.549, $p=0.002$ and $\beta: 0.595, p=0.001$, respectively).

Conclusion: The study results suggested that serum levels of $\lg \mathrm{A} a C L$ and $\lg \mathrm{A} a \beta_{2}$-GPI antibodies are elevated in the active stage of pediatric HSP, indicating that anti-phospholipid antibodies may play a role in the onset of disease. Therefore, we believe that the levels of serum anti-phospholipid antibodies may be an indicator of childhood HSP activity.

Key words: Anticardiolipin antibodies; childhood; Henoch-Schönlein purpura; serum IgA; $\beta_{2}$-glycoprotein I.
Amaç: Bu çalışmada çocukluk çağı Henoch-Schönlein purpurasında (HSP) serum immünoglobulin A ( $\lg A)$ antifosfolipid (aFL) antikorların olası rolü araştırıldı.

Hastalar ve yöntemler: Bu çalışmaya 30 HSP'li (12 erkek, $18 \mathrm{kız}$; ort. yaş $9.0 \pm 3.1 \mathrm{yıl}$; dağılım 4-16 yıl) ve aynı yaş ve cinsiyette 30 sağlıklı çocuk alındı. Serum immünoglobulin düzeyleri, akut faz reaktanları ve diğer biyokimyasal parametrelerin yanı sıra, serum IgA sınıfı antikardiyolipin antikorlar $\left(\lg A\right.$ aKL) ve $\lg A$ sınıfı anti- $\beta_{2}$-glikoprotein I antikorlar ( $\left.\lg \mathrm{A} a \beta_{2}-\mathrm{GPI}\right)$ ölçüldü. $\mathrm{Bu}$ hastalardan kan örnekleri hem akut hem de iyileşme dönemlerinde alındı ve $\lg A$ aKL ve $\lg A$ a $\beta_{2}$-GPI antikorları enzim bağlı immünosorbent test (ELISA) yöntemiyle belirlendi.

Bulgular: Serum $\lg A$ aKL ve $\lg A$ a $\beta_{2}$-GPI düzeyleri HSP tanılı çocuklarda kontrol grubuna göre anlamlı düzeyde yüksekti (sırasıyla, 1.57 $\pm 0.31 \mathrm{U} / \mathrm{mL}^{\prime} y e$ kıyasla $2.12 \pm 0.56 \mathrm{U} / \mathrm{mL}, p<0.001$ ve $0.69 \pm 0.64 \mathrm{U} / \mathrm{mL}^{\prime} y e$ kıyasla $2.32 \pm 1.84 \mathrm{U} / \mathrm{mL}, \quad p<0.001)$. Bu antikorların düzeyleri hastalığın remisyon evresinde anlamlı olarak azaldı. Regresyon analizinde, $\operatorname{artm} ı s ̧ \lg A$ aKL ve $\lg A$ a $\beta_{2}$-GPI antikorlarının tek bağımsız belirleyicisinin serum $\lg A$ düzeyleri olduğu belirlendi (sırasıyla, $\beta$ : 0.549, $p=0.002$ ve $\beta: 0.595, p=0.001)$.

Sonuç: Çalışma bulguları pediatrik HSP'nin aktif döneminde serum IgA aKL ve IgA a $\beta_{2}$-GPI antikorlarının arttığını ve bu nedenle antifosfolipid antikorların bu hastalığın başlangıcında rol oynayabileceğini göstermiştir. Bu nedenle, serum antifosfolipid antikor düzeylerinin çocukluk çağı HSP aktivitesinin bir göstergesi olabileceğine inanıyoruz.

Anahtar sözcükler: Antikardiyolipin antikorlar; çocukluk çağı; HenochSchönlein purpurası; serum IgA; $\beta_{2}$-glikoprotein I.

Received: February 8, 2012 Accepted: June 26, 2012

Correspondence: Mahmut Çivilibal, M.D. Haseki Eğitim ve Araştırma Hastanesi Çocuk Sağlığı ve Hastalıkları Kliniği, 34096 Aksaray, Fatih, İstanbul, Turkey. Tel: +90 212 - 5294400 e-mail: drcivilibal@hotmail.com 
Henoch-Schönlein purpura (HSP) is a small vessel vasculitis with multi-organ involvement that includes the skin, gastrointestinal tract, joints, and kidneys with variable clinical expression. With an annual incidence of approximately 14 cases per 100.000 children, HSP is the most frequent vasculitis in childhood. This disease is often self-limiting, although it may lead to long-term renal morbidity. ${ }^{[1,2]}$

The clinical features are now well recognized; however, there remains uncertainty about the pathogenesis. Henoch-Schönlein purpura is generally believed to be an immune complex-mediated disease characterized by the presence of immune complexes containing polymeric immunoglobulin A1 (pIgA1). Identifying IgA that has been deposited in the vessel wall as well as in the glomerular mesangial area allows for a clear-cut distinction between HSP and other systemic vasculitides or collagen diseases with similar multi-organ involvement. ${ }^{[3]}$

Antiphospholipid syndrome (APS) is increasingly recognized as the most commonly acquired hypercoagulation state of autoimmune etiology and may occur as an isolated clinical entity (primary APS) or in association with an underlying systemic disease, particularly systemic lupus erythematosus (SLE). Antiphospholipid (aPL) antibodies may play a role in a variety of disorders, including autoimmune, malignant, and infectious diseases other than APS and SLE. These antibodies are a heterogeneous group of immunoglobulins that bind to several anionic phospholipids, such as cardiolipin and phosphatidylserine. In addition, there is growing interest in the IgA class anticardiolipin antibodies (IgA aCL). Most aPL antibodies require a serum cofactor known as $\beta_{2}$-glycoprotein I $\left(\beta_{2}\right.$-GPI) for optimal binding. ${ }^{[4,5]}$ Two adult HSP studies have suggested that aPL antibodies are closely related to the pathogenic factors that trigger the development of vasculitis. ${ }^{[6,7]}$ However, the presence and possible role of aPL antibodies in childhood HSP is yet unknown. The aim of this study was to assess the role of these antibodies in the pathogenesis of pediatric HSP.

\section{PATIENTS AND METHODS}

This study was made between January 2010 and January 2011. The diagnosis of HSP was made according to the European League Against Rheumatism (EULAR) and the Paediatric Rheumatology European Society (PRES) criteria. ${ }^{[3]}$ Thirty children in the acute phase of HSP (12 boys, 18 girls; mean age $9.0 \pm 3.1$ years; range 4 to 16 years) and 30 healthy children (15 boys, 15 girls; mean age $9.2 \pm 3.3$ years; range 4 to 16 years) were enrolled in this study, and the participants were matched according to age and gender. None of the patients had been given corticosteroids, immunosuppressants, or vasodilators at the time of serum sampling. Furthermore, no patient demonstrated any evidence of coexisting malignancy, other autoimmune diseases, or viral infections. The control group was recruited from healthy children with no history of hypertension or renal or cardiac diseases and no family history of any nephrologic disease among first-degree relatives.

A detailed medical history was obtained, and thorough physical examinations and routine laboratory tests were performed for all patients. The patients with HSP and the healthy controls were checked for complete blood count (CBC), erythrocyte sedimentation rate (ESR), high-sensitivity C-reactive protein (hs-CRP), serum electrolytes, glucose, urea, creatinine, uric acid, total protein, albumin, total cholesterol, triglycerides, immunoglobulin $\mathrm{G}$ ( $\operatorname{IgG}$ ), IgA, immunoglobulin $\mathrm{M}$ (IgM), immunoglobulin E (IgE), and complements 3 and 4 (C3 and C4). A urinalysis was done. The following tests were negative or within the reference range in all HSP patients: thrombocyte count, prothrombin time (PT), active partial thromboplastin time (aPTT), C3, C4, antinuclear antibody (ANA), antidouble-stranded DNA (anti-dsDNA), antineutrophil cytoplasmic antibodies (pANCA and cANCA), cryoglobulin, bacterial cultures, and virus serology including hepatitis $\mathrm{A}, \mathrm{B}$, and $\mathrm{C}$.

Blood samples from the HSP patients were collected at both acute and remission (10-12 weeks later) stages. Based on the tests carried out before the study, none of the patients had any other systemic disease. All patients achieved a complete clinical recovery. We did not perform a percutaneous renal biopsy on patients with HSP because there were no indications that it was necessary.

The local research ethics committee approved this study protocol, and written informed consent was obtained from the children over 12 years old and from the parents of all subjects. Our examinations of the patients conformed to good medical and laboratory practices and the recommendations of the Declaration of Helsinki.

Venous blood samples were collected from each patient in standard sterile evacuated blood collection tubes containing either ethylenediaminetetraacetic acid (EDTA) or no additive at all. The plasma or serum 
samples were prepared after centrifugation at $3000 \mathrm{rpm}$ (1600xg) for 10 minutes and were stored at $-70{ }^{\circ} \mathrm{C}$ until the assay. All measurements were performed in duplicate, and all plasma or serum samples were analyzed simultaneously using the commercial Abbott C-16000 autoanalyzer kit (Abbott Laboratories, Abbott Park, Illinois, USA). The antibodies IgA aCL and IgA a $\beta_{2}$-GPI were measured by a commercially standardized enzymelinked immunosorbent assay (ELISA) kit (ORGENTEC Diagnostics, Mainz, Germany).

\section{Statistical analysis}

All the analyses were performed using the Statistical Package for the Social Sciences (SPSS Inc., Chicago, Illinois, USA) version 17.0 software program for Windows. To compare a continuous variable between the two groups, Student's unpaired t-test and the MannWhitney $U$ test were used respectively for variables with normal and skewed distributions. Continuous variables with normal distributions were expressed as mean standard deviation $( \pm S D)$, and those with skewed distributions were expressed as a median (interquartile range). To compare categorical variables between the two groups, Fisher's exact test was performed. Categorical variables were described as the number of subjects expressed as a percentage in each category. A paired samples t-test was used to determine the differences between the active and remission stages of HSP. The strength of the associations between variables was measured using Spearman's correlation coefficient. A stepwise linear regression analysis was performed to assess the independent predictors of aPL antibodies. A $p$ value of less than 0.05 was considered significant.

\section{RESULTS}

All patients had typical diffuse erythematous palpable purpuric lesions on the lower extremities and buttocks. There was abdominal pain with or without gastrointestinal bleeding in 28 patients (93\%). Arthritis or arthralgia was noted in 22 patients (77\%). Only four patients (13\%) developed glomerulonephritis at the onset of the disease. Two of them had renal involvement with microscopic hematuria, and the other two presented with microscopic hematuria and mild proteinuria. None of the patients had nephrotic-range proteinuria or renal dysfunction. Microscopic hematuria and mild or moderate proteinuria disappeared at the end of two months in these patients.

No significant differences were found between the serum glucose, urea, creatinine, total protein, albumin, triglycerides, total cholesterol, IgG, IgM, C3, or C4 levels

Table 1. Demographic and biochemical characteristics of Henoch-Schönlein purpura patients and controls.

\begin{tabular}{|c|c|c|c|c|c|c|c|c|}
\hline & \multicolumn{2}{|c|}{$\begin{array}{l}\text { HSP active stage } \\
\qquad(\mathrm{n}=30)\end{array}$} & \multicolumn{2}{|c|}{$\begin{array}{l}\text { HSP remission } \\
\quad(n=30)\end{array}$} & \multicolumn{2}{|r|}{$\begin{array}{l}\text { Control } \\
(n=30)\end{array}$} & \multirow[b]{2}{*}{$p^{*}$} & \multirow[b]{2}{*}{$p^{* *}$} \\
\hline & $\mathrm{n}$ & Mean \pm SD & $\mathrm{n}$ & Mean \pm SD & $\mathrm{n}$ & Mean \pm SD & & \\
\hline Age (years) & & $9.0 \pm 3.1$ & & $9.2 \pm 3.1$ & & $9.2 \pm 3.3$ & 0.852 & 0.685 \\
\hline \multicolumn{9}{|l|}{ Gender } \\
\hline Boy & 18 & & 18 & & 15 & & 1.000 & 0.302 \\
\hline Girl & 12 & & 12 & & 15 & & 1.000 & 0.302 \\
\hline Glucose (mg/dl) & & $92 \pm 14$ & & $91 \pm 8$ & & $91 \pm 7$ & 0.502 & 0.699 \\
\hline Urea $(\mathrm{mg} / \mathrm{dl})$ & & $25 \pm 5$ & & $23 \pm 5$ & & $23 \pm 4$ & 0.245 & 0.193 \\
\hline Creatinine (mg/dl) & & $0.55 \pm 0.09$ & & $0.55 \pm 0.08$ & & $0.57 \pm 0.10$ & 0.198 & 0.230 \\
\hline Total protein $(\mathrm{g} / \mathrm{dl})$ & & $7.2 \pm 0.5$ & & $7.2 \pm 0.4$ & & $7.3 \pm 0.4$ & 0.698 & 0.782 \\
\hline Albumin (g/dl) & & $4.1 \pm 0.3$ & & $4.2 \pm 0.3$ & & $4.1 \pm 0.3$ & 0.878 & 0.991 \\
\hline Triglycerides (mg/dl) & & $117 \pm 92$ & & $109 \pm 86$ & & $97 \pm 36$ & 0.698 & 0.656 \\
\hline Total cholesterol & & $140 \pm 28$ & & $149 \pm 32$ & & $144 \pm 27$ & 0.788 & 0.905 \\
\hline $\operatorname{ESR}(\mathrm{mm} / \mathrm{h})$ & & $28 \pm 20$ & & $6.4 \pm 2.4$ & & $5.4 \pm 2.2$ & $<0.001$ & $<0.001$ \\
\hline hs-CRP (mg/l) & & $5.5 \pm 7.8$ & & $0.21 \pm 0.18$ & & $0.14 \pm 0.15$ & $<0.001$ & $<0.001$ \\
\hline $\operatorname{IgG}(\mathrm{mg} / \mathrm{dl})$ & & $1230 \pm 390$ & & $1125 \pm 360$ & & $1090 \pm 357$ & 0.230 & 0.345 \\
\hline IgA (mg/dl) & & $201 \pm 66$ & & $196 \pm 62$ & & $145 \pm 52$ & 0.765 & 0.006 \\
\hline $\operatorname{IgM}(\mathrm{mg} / \mathrm{dl})$ & & $124 \pm 56$ & & $131 \pm 58$ & & $119 \pm 52$ & 0.432 & 0.123 \\
\hline C3 (mg/dl) & & $143 \pm 34$ & & $136 \pm 35$ & & $137 \pm 45$ & 0.586 & 0.656 \\
\hline $\mathrm{C} 4$ (mg/dl) & & $39 \pm 35$ & & $36 \pm 27$ & & $41 \pm 29$ & 0.224 & 0.112 \\
\hline
\end{tabular}


Table 2. Antiphospholipid antibody levels of Henoch-Schönlein purpura patients and controls

\begin{tabular}{|c|c|c|c|c|c|}
\hline & $\begin{array}{l}\text { HSP active stage } \\
(\mathrm{n}=30)\end{array}$ & $\begin{array}{l}\text { HSP remission } \\
\quad(\mathrm{n}=30)\end{array}$ & $\begin{array}{c}\text { Control } \\
(\mathrm{n}=30)\end{array}$ & & \\
\hline & Mean \pm SD & Mean \pm SD & Mean \pm SD & $p^{*}$ & $p^{* *}$ \\
\hline $\operatorname{IgA} \mathrm{aCL}(\mathrm{U} / \mathrm{ml})$ & $2.12 \pm 0.56$ & $1.80 \pm 0.48$ & $1.57 \pm 0.31$ & 0.022 & $<0.001$ \\
\hline IgA a $\beta_{2}-\mathrm{GPI}(\mathrm{U} / \mathrm{ml})$ & $2.32 \pm 1.84$ & $1.55 \pm 2.50$ & $0.58 \pm 0.64$ & $<0.001$ & $<0.001$ \\
\hline
\end{tabular}

in the HSP patients and the controls. The ESR and hs-CRP levels of the HSP patients in the active stage were significantly higher than the levels in patients in the remission stage and the control group. The IgA levels of the HSP patients in the active stage were significantly higher than in the controls, but the levels did not differ between the active and remission stages (Table 1).

The levels of the serum IgA aCL and IgA a $\beta_{2}$-GPI antibodies were significantly higher in the active stage of HSP compared with the patients in the remission stage and the controls, and both antibodies decreased significantly during the remission stage (Table 2) (Figures 1 and 2).

The univariate analysis of factors that correlated with the serum IgA aCl and IgA a $\beta_{2}$-GPI antibodies are shown in Table 3. We found a positive correlation between these two antibodies; however, neither the IgA $\mathrm{aCl}$ nor the IgA a $\beta_{2}$-GPI levels were associated with

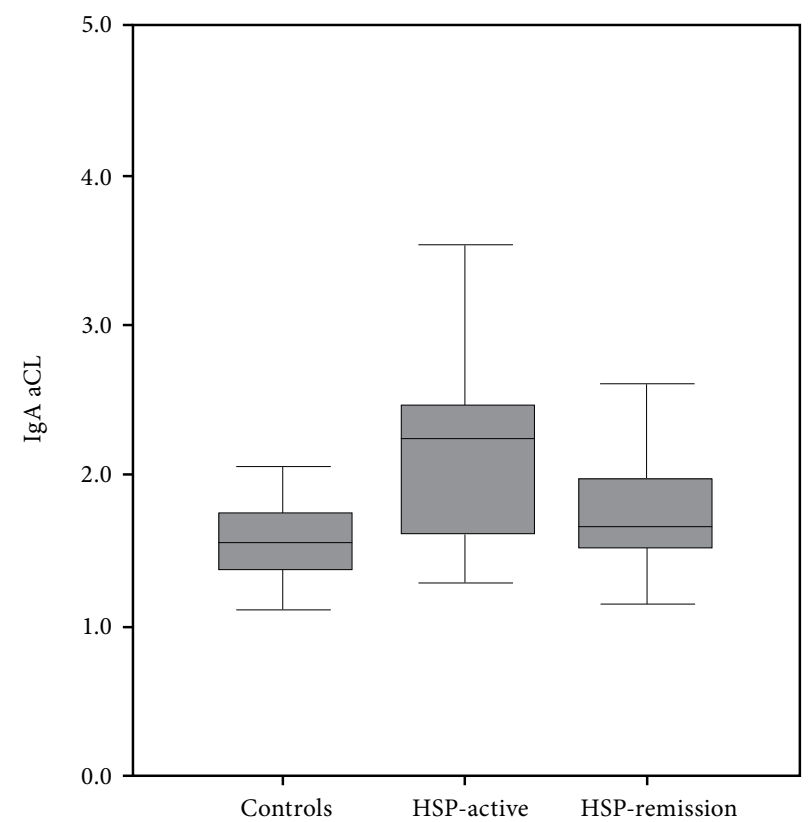

Figure 1. Comparison of $\operatorname{IgA}$ anti-cardiolipin antibody (IgA aCL) levels between study groups. HSP: Henoch-Schönlein purpura. acute phase reactants such as ESR and hs-CRP. In the regression analysis, the mean serum IgA level was the only independent predictor of the increased $\operatorname{IgA} \mathrm{aCL}$ and $\operatorname{IgA} a \beta_{2}$-GPI antibodies $(\beta$ : 0.549, $\mathrm{p}=0.002$ and $\beta: 0.595, \mathrm{p}=0.001$, respectively).

\section{DISCUSSION}

Although HSP is the most common vasculitis in childhood, its etiopathogenesis remains undetermined. Patients with HSP characteristically show prominent deposits of IgA in the vessel wall and the glomerular mesengial area. This finding allows a clear-cut distinction between HSP and other systemic vasculitides or collagen diseases.

In the present study, the ESR, hs-CRP, and IgA levels were elevated at the active phase of the disease, which is similar to what was determined in previous studies. $^{[6-8]}$ The serum IgG and IgM levels of our

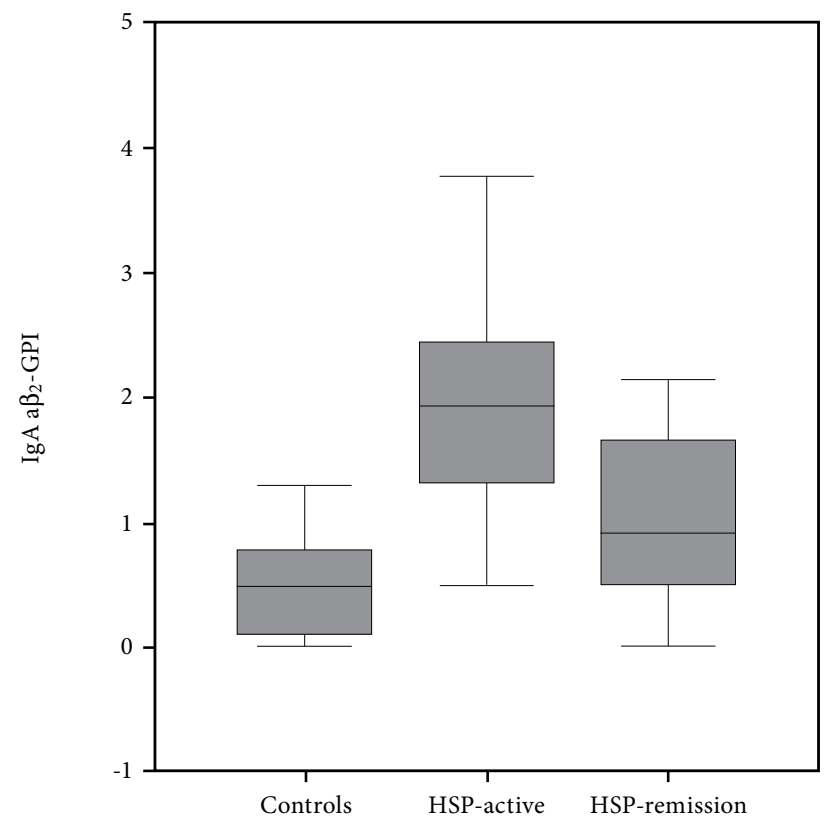

Figure 2. Comparison of IgA anti- $\beta_{2}$-glycoprotein I (IgA a $\beta_{2}$-GPI) levels between study groups. HSP: Henoch-Schönlein purpura. 


\begin{tabular}{|c|c|c|c|c|}
\hline & \multicolumn{2}{|c|}{$\operatorname{IgA~aCl}$} & \multicolumn{2}{|c|}{$\operatorname{IgA} \mathrm{a} \beta_{2}-\mathrm{GPI}$} \\
\hline & $\mathrm{r}$ & $p$ & $\mathrm{r}$ & $p$ \\
\hline Age & 0.397 & 0.015 & 0.332 & 0.037 \\
\hline Height & - & - & 0.342 & 0.041 \\
\hline Creatinine & - & - & 0.338 & 0.043 \\
\hline Total protein & 0.358 & 0.026 & - & - \\
\hline Globulin & 0.474 & 0.004 & - & - \\
\hline Hemoglobin & 0.337 & 0.034 & 0.382 & 0.019 \\
\hline Serum IgA & 0.416 & 0.011 & 0.382 & 0.019 \\
\hline $\operatorname{IgA~aCl}$ & 1.000 & - & 0.694 & $<0.001$ \\
\hline $\operatorname{IgA~a} \beta_{2}-\mathrm{GPI}$ & 0.694 & $<0.001$ & 1.000 & - \\
\hline
\end{tabular}

patients did not differ from those in the controls, but the serum immunoglobulin $\mathrm{D}$ (IgD) levels were not measured. The elevation of acute phase reactants reflected the possible nature of the acute inflammatory process, and the increased serum IgA levels showed the immunological effects of HSP. Another study reported a marked increase in IgA-bearing lymphocytes in the peripheral blood during the acute phase of the disease. ${ }^{[9]}$ It is known that IgA complexes may be dissolved by complement and that they may activate the alternative complement pathway. ${ }^{[10]}$

The main purpose of our study was to determine the aPL antibody levels in children with HSP. Antiphospholipid antibodies occur in a variety of autoimmune, malignant, and infectious diseases, either with or without the thrombotic or obstetric sequelae that characterize the aPL syndrome. Although many studies have focused on the clinical implications of aPL in SLE, few have specifically addressed the questions facing rheumatologists who care for those patients who are concomitantly positive for aPL. ${ }^{[1]}$

The presence of aPL antibodies does not automatically mean that an individual will suffer from aPL syndrome-related symptoms. These antibodies in children may or may not be associated with another autoimmune disease. ${ }^{[12]}$ The aPL may play a role in a variety of disorders apart from APS, and it has long been recognized that aPL occurs at a high frequency in many disorders other than APS and SLE, especially those known to be immune-mediated such as immune thrombocytopenic purpura, multiple sclerosis, and RA. ${ }^{[13]}$ In addition, it has been reported that the level of $\operatorname{IgA}$ aCL is increased in the patients with Behçet's disease and livedoid vasculitis. ${ }^{[14,15]}$
The antibodies which are directed against phospholipids are a heterogeneous group of immunoglobulins of the IgG, IgM and IgA classes. Among them, great interest has been in the IgA class. We found that the serum IgA aCL and IgA a $\beta_{2}$-GPI antibody levels were significantly higher in the active stage of disease. The IgG and IgM classes of these antibodies were not detected in our patients. Yang et al. ${ }^{[8]}$ similarly demonstrated a significant association between IgA aCL antibodies and childhood HSP during the acute stage. Based on these findings, serum IgA aCL and/or IgA a $\beta_{2}$-GPI antibody levels could serve as a marker for pediatric HSP; therefore, they should be monitored to appropriately gauge disease activity. In addition, elevated antibody levels may imply involvement of immunologic elements in the pathogenesis of HSP.

Similar results have been detected in adult patients with HSP. ${ }^{[6,7]}$ In two studies performed by Kawakami et al. ${ }^{[6,7]}$ serum IgA aCL antibodies were elevated in patients with arthralgia and/or proteinuria versus those without these maladies. They suggested that monitoring serum IgA aCL antibody levels might be useful, especially for predicting renal involvement. In our study, the number of subjects per category, including arthritis/arthralgia, gastrointestinal involvement, and glomerulonephritis, were not enough to make comparisons; therefore, this situation was difficult to fully interpret.

We successfully identified the factors associated with the increased aPL antibodies in our patients. There was a significant positive correlation between the serum IgA aCl and IgA a $\beta_{2}$-GPI antibodies, and this was actually an expected result. One serum protein, $\beta_{2}$-GPI, had a high affinity for anionic phospholipids, 
a requirement for binding $\operatorname{Ig} \mathrm{A}$ aCL to cardiolipins in autoimmune disease. Similar correlations were also seen between these two antibodies and age, height, serum creatinine, total protein, globulin, hemoglobin, and IgA levels. In regression analysis, we identified that the mean serum IgA level was the only independent predictor for the increased IgA aCL and IgA a $\beta_{2}$-GPI antibodies. This is one of the most important results of our study. Yang et al..$^{[8]}$ similarly demonstrated a significant association between IgA aCL and childhood HSP during the acute stage.

A crucial question is whether elevated $\operatorname{IgA}$ aCL and $\operatorname{IgA}$ a $\beta_{2}$-GPI antibodies are acute phase reactants. In our study, these antibodies were not associated with ESR and hs-CRP. However, Kawakami et al. ${ }^{[6]}$ found a significant correlation between serum $\operatorname{IgA}$ aCL antibodies and CRP in adult patients with HSP. To prove this, additional research and comparisons should be made, but these results should be comparable with the diseased controls, such as other inflammatory diseases. Additionally, the IgG class antibodies against phospholipids should be measured to determine if they are specific for HSP.

In conclusions, we found high titers of serum IgA aCL and IgA a $\beta_{2}$-GPI antibodies in pediatric HSP patients, and there was a significant association between these two markers. Both antibodies decreased significantly during the remission stage. Therefore, their detection may be valuable in the monitoring of disease activity. We also found a significant positive correlation between these antibodies and the serum IgA level. These findings suggest that IgA abnormalities are closely related to the pathogenic factors that trigger the development of HSP. However, further studies are required to confirm the pathogenesis of HSP.

\section{Declaration of conflicting interests}

The authors declared no conflicts of interest with respect to the authorship and/or publication of this article.

\section{Funding}

The authors received no financial support for the research and/or authorship of this article.

\section{REFERENCES}

1. Mills JA, Michel BA, Bloch DA, Calabrese LH, Hunder GG, Arend WP, et al. The American College of Rheumatology 1990 criteria for the classification of Henoch-Schönlein purpura. Arthritis Rheum 1990;33:1114-21.
2. Nielsen HE. Epidemiology of Schönlein-Henoch purpura. Acta Paediatr Scand 1988;77:125-31.

3. Ozen S, Pistorio A, Iusan SM, Bakkaloglu A, Herlin T, Brik R, et al. EULAR/PRINTO/PRES criteria for Henoch-Schönlein purpura, childhood polyarteritis nodosa, childhood Wegener granulomatosis and childhood Takayasu arteritis: Ankara 2008. Part II: Final classification criteria. Ann Rheum Dis 2010;69:798-806.

4. McNeil HP, Chesterman CN, Krilis SA. Immunology and clinical importance of antiphospholipid antibodies. Adv Immunol 1991;49:193-280.

5. McNeil HP, Simpson RJ, Chesterman CN, Krilis SA. Anti-phospholipid antibodies are directed against a complex antigen that includes a lipid-binding inhibitor of coagulation: beta 2-glycoprotein I (apolipoprotein $\mathrm{H}$ ). Proc Natl Acad Sci U S A 1990;87:4120-4.

6. Kawakami T, Watabe H, Mizoguchi M, Soma Y. Elevated serum IgA anticardiolipin antibody levels in adult HenochSchönlein purpura. Br J Dermatol 2006;155:983-7.

7. Kawakami T, Yamazaki M, Mizoguchi M, Soma Y. High titer of serum antiphospholipid antibody levels in adult Henoch-Schönlein purpura and cutaneous leukocytoclastic angiitis. Arthritis Rheum 2008;59:561-7.

8. Yang YH, Huang MT, Lin SC, Lin YT, Tsai MJ, Chiang $\mathrm{BL}$. Increased transforming growth factor-beta (TGFbeta)-secreting $\mathrm{T}$ cells and $\operatorname{IgA}$ anti-cardiolipin antibody levels during acute stage of childhood Henoch-Schönlein purpura. Clin Exp Immunol 2000;122:285-90.

9. Kuno-Sakai H, Sakai H, Nomoto Y, Takakura I, Kimura M. Increase of IgA-bearing peripheral blood lymphocytes in children with Henoch-Schoenlein purpura. Pediatrics 1979;64:918-22.

10. Hiemstra PS, Biewenga J, Gorter A, Stuurman ME, Faber A, van Es LA, et al. Activation of complement by human serum $\operatorname{IgA}$, secretory $\operatorname{IgA}$ and $\operatorname{IgA} 1$ fragments. Mol Immunol 1988;25:527-33.

11. Gladd DA, Olech E. Antiphospholipid antibodies in rheumatoid arthritis: identifying the dominoes. Curr Rheumatol Rep 2009;11:43-51.

12. Derksen RH, de Groot PG. Clinical consequences of antiphospholipid antibodies. Neth J Med 2004; $62: 273-8$.

13. Horstman LL, Jy W, Bidot CJ, Ahn YS, Kelley RE, Zivadinov R, et al. Antiphospholipid antibodies: paradigm in transition. J Neuroinflammation 2009 20;6:3.

14. Zivkovic M, Zlatanovic M, Zlatanovic G, Djordjevic-Jocic J, Cekic S. Anticardiolipin antibodies in patients with Behcet's disease. Bosn J Basic Med Sci 2011;11:58-61.

15. Feng SY, Jin PY, Shao CG. The significance of anticardiolipin antibody and immunologic abnormality in livedoid vasculitis. Int J Dermatol 2011;50:21-3. doi: 10.1111/j.1365-4632.2010.04569.x. 